
\title{
of growing crossbred calves
}

\author{
[Substituição da ureia por farelo de soja e consumo forçado de minerais no desempenho \\ de bezerros em crescimento] \\ J.J. Ferreira ${ }^{1}$, J.R.M. Ruas $^{2,3}$, G.A.R. Macedo ${ }^{1}$, A. Marcatti Neto ${ }^{1}$, D.S. Queiroz ${ }^{1}$, E.A. Silva ${ }^{1}$ \\ ${ }^{1}$ Empresa de Pesquisa Agropecuária de Minas Gerais - Belo Horizonte, MG \\ ${ }^{2}$ Universidade Estadual de Montes Claros - Janaúba, MG \\ ${ }^{3}$ Bolsista de Produtividade em pesquisa $-\mathrm{CNPq}$
}

\begin{abstract}
Forty eight crossbred calves, 24 males and 24 females, with weight and age of $203.6 \pm 3.7 \mathrm{~kg}$ and $11.8 \pm 1.0$ months were allotted to the following treatments: MT- mineral salt ad libitum and sugar cane mixed with $10 \mathrm{~g} \mathrm{~kg}^{-1}$ mixture of urea and ammonium sulfate in a 9:1 proportion; MA - sugar cane mixed with $16 \mathrm{~g} \mathrm{~kg}^{-1}$ of a concentrate of urea $\left(550 \mathrm{~g} \mathrm{~kg}^{-1}\right)$, ammonium sulfate $\left(60 \mathrm{~g} \mathrm{~kg}^{-1}\right)$ and minerals $\left(390 \mathrm{~g} \mathrm{~kg}^{-1}\right)$; SU - sugar cane mixed with $50 \mathrm{~g} \mathrm{~kg}^{-1}$ of a concentrate of soybean meal $\left(830 \mathrm{~g} \mathrm{~kg}^{-1}\right)$, urea $\left(52 \mathrm{~g} \mathrm{~kg}^{-1}\right)$ and minerals $\left(118 \mathrm{~g} \mathrm{~kg}^{-1}\right)$ and $\mathrm{MC}$ - corn silage mixed with $10 \mathrm{~g} \mathrm{~kg}^{-1}$ of a concentrate of urea $\left(500 \mathrm{~g} \mathrm{~kg}^{-1}\right)$, ammonium sulfate $\left(50 \mathrm{~g} \mathrm{~kg}^{-1}\right)$ and minerals $\left(450 \mathrm{~g} \mathrm{~kg}^{-1}\right)$. Minerals mixed with sugar cane (MA) resulted in greater weight gain $\left(0.258 \times 0.188 \mathrm{~kg} \mathrm{~d}^{-1}\right)$ for similar intakes of DM $\left(3.29 \times 3.30 \mathrm{~kg} \mathrm{~d}^{-1}\right)$. Substitution of part of urea nitrogen in the MA by soybean meal (SU) resulted in greater ADG $\left(0.538 \times 0.258 \mathrm{~kg} \mathrm{~d}^{-1}\right)$, due to higher sugar cane intake $\left(4.10 \times 3.13 \mathrm{~kg} \mathrm{~d}^{-1}\right)$. ADG of calves receiving corn silage was greater $(0.406 \mathrm{x}$ $0.258 \mathrm{~kg} \mathrm{~d}^{-1}$ ) than for calves receiving sugar cane.
\end{abstract}

Keywords: calves, corn silage, minerals, sugar cane, weight gain

\section{RESUMO}

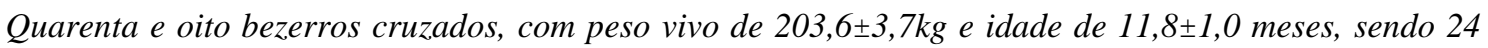
machos e 24 fêmeas, foram distribuídos nos tratamentos: MT - sal mineral à vontade e cana-de-açúcar adicionada de $10 \mathrm{~g} \mathrm{~kg}^{-1}$ de uma mistura de ureia e sulfato de amônio na proporção de 9:1; MA - cana-deaçúcar adicionada de $16 \mathrm{~g} \mathrm{~kg}^{-1}$ de uma mistura de ureia (55\%), sulfato de amônio (6\%) e minerais (39\%); $S U$ - cana-de-açúcar adicionada de $50 \mathrm{~g} \mathrm{~kg}^{-1}$ de uma mistura de farelo de soja (83\%), ureia (5,2\%) $e$ minerais (11,8\%); e MC - silagem de milho adicionada de $10 \mathrm{~g} \mathrm{~kg}^{-1}$ de uma mistura de ureia (50\%), sulfato de amônio (5\%) e minerais (45\%). Minerais misturados no volumoso resultaram em maior ganho de peso (0, $258 \times$ 0,188kg/dia) com consumos semelhantes de matéria seca $(3,29 \times 3,30 \mathrm{~kg} /$ dia $)$. Substituição de parte do nitrogênio da ureia no MA pelo do farelo de soja resultou em aumento do ganho de peso $(0,258 \times 0,538 \mathrm{~kg} /$ dia $)$ e no consumo de cana $(3,13 \times 4,10 \mathrm{~kg} /$ dia $)$. Ganho de peso dos bezerros que receberam silagem de milho foi superior ao dos bezerros que receberam o MA $(0,406 \times 0,258 \mathrm{~kg} /$ dia $)$, devido ao maior consumo de silagem $(4,71 \times 3,13 \mathrm{~kg} /$ dia $)$.

Palavras-chave: bezerros, cana-de-açúcar, silagem de milho, ganho de peso, minerais

\section{INTRODUCTION}

The production of sugar cane in Brazil in 2016 was 694.54 million tons. Of that amount it was estimated that about $10 \%$ was used for forage. The low protein content is the most evident

Recebido em 10 de janeiro de 2018

Aceito em 17 de janeiro de 2019

E-mail: jucaferreira2008@yahoo.com.br limitation and the high content of sucrose is the main advantage of sugar cane as bovine feed. Sucrose is rapidly fermented and urea is enzymatically converted into ammonia and carbon dioxide in the rumen. The relationship between the fermentable nitrogen content of the diet and the rumen microbial growth was 
reported by Allen and Miller (1977). It was found that one hundred grams of fermented carbohydrate was needed for three grams of fermentable nitrogen in the rumen. Practical confirmation of that relationship was shown by Alvarez and Preston (1976) who found that $30 \mathrm{~g}$ of urea $\mathrm{kg}^{-1}$ of sugar cane dry matter was the best level for cattle feeding. Not only the low protein content and fiber digestibility were associated with the low intake of sugar cane, but also an unbalance of minerals in the diet and the small amounts of glucose and aminoacids available pos-ruminally (Preston et al., 1976). So it is important to know the concentration and the digestion site of each nutrient to maintain a steady and balanced supply of nutrients to the animal and the microorganisms of the rumen (Lima et al., 2002). The purpose of this experiment was to evaluate the performance of crossbred calves supplemented with minerals mixed with chopped sugar cane or corn silage or with replacement of part of the urea nitrogen with soybean meal nitrogen in the sugar cane diet.

\section{MATERIAL AND METHODS}

The experiment was carried out at the Experimental Farm of Felixlandia of Empresa de Pesquisa Agropecuária de Minas Gerais located in the county of Felixlandia, latitude $18^{\circ} 42^{\prime} \mathrm{S}$, longitude $44^{\circ} 55^{\prime} \mathrm{W}$ and altitude $604 \mathrm{~m}$, Minas Gerais State, in Brazil. Twenty four male and twenty four female $3 / 4$ Zebu x Holstein calves with an average weight of $203.6 \pm 3.7 \mathrm{~kg}$ and age of $11.8 \pm 1.0$ months were assigned to four treatments, in a complete block design. The treatments were as follows: MT- chopped sugar cane mixed with urea and ammonium sulfate in a 9:1 proportion added at a rate of $10 \mathrm{~g} \mathrm{~kg}^{-1}$ of fresh matter and mineral salt offered ad libitum in the trough; MA - chopped sugar cane mixed with $16 \mathrm{~g} \mathrm{~kg}^{-1}$ (Nitromineral) of a concentrate of urea, ammonium sulfate and minerals, to contain the same amount of urea and ammonium sulfate per $\mathrm{kg}$ of sugar cane as in treatment MT; SU chopped sugar cane mixed with $50 \mathrm{~g} \mathrm{~kg}^{-1}$ (Nitroprotein concentrate) of a concentrate of soybean meal, urea and minerals, to contain the same amount of nitrogen as in treatments MA and $\mathrm{MC}$ - corn silage mixed with $10 \mathrm{~g} \mathrm{~kg}^{-1}$ of a concentrate of urea, ammonium sulfate and minerals, to contain the same amount of nitrogen as in treatment MA.
The ingredients and nutrient composition of the experimental concentrates and the amounts added per $\mathrm{kg}$ of forage fed is shown in Table 1. The first 14 days was the adaptation period and the following 140 days the experimental period. The roughage was offered once a day, the concentrates spread on top of it and mixed in the morning after the refusals were collected, weighed and discarded. The amount of roughage offered was adjusted every three days and refusals were kept in the range of six to eight per cent of the amount offered, on a fresh weight basis. In treatment MT, the mineral salt (Icalfós ICA, Industria de calcinação Ltda, Brazil) was offered in a sheltered trough, ad libitum. Every seven days, the mineral salt left in the trough was collected and weighed to calculate the average daily intake.

The calves were weighed every 28 days at 7:00 in the morning, after a $16 \mathrm{~h}$ fast from feed and water. Samples of the forage fed were collected twice a week in the morning and the samples of the respective refusals were collected the following morning. Samples of the mineral salts were taken once a week from the respective refusals. The samples were composited every 28 days and analyzed for dry matter, crude protein, calcium, phosphorus, magnesium, potassium, sulfur, sodium, copper, zinc and manganese, using the methods described in (Official..., 1995).

Sequential detergent fiber analysis were used to determine the NDF (Van Soest et al., 1991) and ADF (Goering and Van Soest, 1970) concentrations of sugar cane, corn silage and soybean meal, with a Tecnal TE-149 Fiber Analyzer (Tecnal Equipamentos para Laboratórios Ltda, Piracicaba, Brazil). The NDF was determined using heat stable $\alpha$-amylase (Ankon Technology, Tecnoglobo Equipamentos, Curitiba, Brazil) and sodium sulfite. Non-fiber carbohydrates (NFC) were estimated according to the following equation: NFC $(\%)=100-(\%$ $\mathrm{NDF}+\% \mathrm{CP}+\%$ ether extract $+\%$ ash). Weight gains were analyzed using the following statistical model with the block effect established by six initial live weight range for males and females. Within each block randomly one male and one female were grouped and the resulting four groups assigned at random to the four treatments. The Newman Keuls test was used for comparison of treatment means: 
$\mathrm{Y}_{\mathrm{ij} 1}=\mu+\mathrm{B}_{\mathrm{i}}+\mathrm{T}_{\mathrm{j}}+\mathrm{BT}_{\mathrm{ij}}+\mathrm{S}_{\mathrm{l}}+\mathrm{BS}_{\mathrm{il}}+\mathrm{TS}_{\mathrm{jl}}+\mathrm{BTS}_{\mathrm{ijl}}$

$\mathrm{Y}_{\mathrm{ijl}}$ - weight gain for each calf in block $(\mathrm{i}=1,2,3,4,5,6)$, treatment $(\mathrm{j}=1,2,3,4)$ and from

$$
\operatorname{sex}(1=1,2)
$$

$\mu$ - overall mean

$\mathrm{B}_{\mathrm{i}}$ - block effect ( $\left.\mathrm{i}=1,2,3,4,5,6\right)$

$\mathrm{T}_{\mathrm{j}}$ - treatment effect $(\mathrm{j}=1,2,3,4)$

$\mathrm{BT}_{\mathrm{ij}-}$ - effect of the interaction of $\mathrm{i}^{\text {th }}$ block with $\mathrm{j}^{\text {th }}$ treatment

$\mathrm{S}_{1}$ - sex effect $(\mathrm{l}=1,2)$

$\mathrm{BS}_{\mathrm{il}}$ - effect of the interaction of $\mathrm{i}^{\text {th }}$ block with $\mathrm{l}^{\text {th }}$ sex

$\mathrm{TS}_{\mathrm{j} 1}$ - effect of the interaction of $\mathrm{j}^{\text {th }}$ treatment with $1^{\text {th }}$ sex

BTS $_{\mathrm{ijl} \text { l }}$ effect of the interaction of $\mathrm{i}^{\text {th }}$ block with $\mathrm{j}^{\text {th }}$ treatment with $\mathrm{l}^{\text {th }}$ sex

The average intake of DM, CP, NDF, ADF, NFC and minerals were obtained for each treatment.

Table 1. Ingredient and nutrient composition of the experimental concentrates and daily amounts added $(\mathrm{g}$ $\mathrm{kg}^{-1}$ of forage fed)

\begin{tabular}{|c|c|c|c|c|}
\hline \multirow{2}{*}{ Item } & \multicolumn{4}{|c|}{ Treatment } \\
\hline & MT & MA & SU & $\mathrm{MC}$ \\
\hline Ingredient & \multicolumn{4}{|c|}{$\mathrm{g} \mathrm{kg}^{-1}$ as fed } \\
\hline Soybean meal & - & -0 & 830 & - \\
\hline Urea & 900 & 550 & 52 & 500 \\
\hline Ammonium sulfate & 100 & 60 & 6 & 50 \\
\hline Limestone & - & - & 12 & 10 \\
\hline Dicalcium phosphate & - & 140 & 20 & 90 \\
\hline Mineral salt & - & 200 & 64 & 320 \\
\hline Common salt & - & 50 & 16 & 30 \\
\hline Nutrient composition & \multicolumn{4}{|c|}{$\mathrm{g} \mathrm{kg}^{-1}$ dry matter } \\
\hline Dry matter & 969.5 & 974.3 & 897.2 & 978.0 \\
\hline Crude protein ${ }^{1}$ & $2,649.0$ & $1,607.0$ & 572.0 & $1,448.0$ \\
\hline NDF & - & - & 131.2 & - \\
\hline $\mathrm{ADF}$ & - & - & 86.9 & - \\
\hline NFC & - & - & 259.8 & - \\
\hline Calcium & - & 51.18 & 18.7 & 58,4 \\
\hline Phosphorus & - & 41.9 & 15.9 & 45.4 \\
\hline Magnesium & - & 3.6 & 3.7 & 5.8 \\
\hline Potassium & - & 0.9 & 20.9 & 1.4 \\
\hline Sodium & - & 47.0 & 18.1 & 54.7 \\
\hline \multirow[t]{2}{*}{ Sulfur } & 21.3 & 20.5 & 8.0 & 22.7 \\
\hline & \multicolumn{4}{|c|}{$\mathrm{mg} \mathrm{kg}^{-1}$} \\
\hline Zinc & - & 884 & 352 & 1410 \\
\hline Copper & - & 395 & 153 & 631 \\
\hline Manganese & - & 515 & 212 & 821 \\
\hline \multirow[t]{2}{*}{ Rate of concentrate feeding } & \multicolumn{4}{|c|}{$\mathrm{g} \mathrm{kg}^{-1}$ of fresh forage } \\
\hline & 10 & 16 & 50 & 10 \\
\hline
\end{tabular}

${ }^{1}$ Crude protein or protein equivalent $(\mathrm{g} \mathrm{N} \times 6.25)$

\section{RESULTS AND DISCUSSION}

The chemical composition of the ingredients used in the experimental diets is shown in Table 2.The corn silage $\mathrm{pH}$ was 3.85 and ammonia nitrogen $6.79 \mathrm{~g} \mathrm{~kg}^{-1}$ of the total nitrogen. The sucrose content of the sugar cane expressed by the Brix level (refractometer measuring) was 20. 
Table 2. Chemical composition ( $\mathrm{g} \mathrm{kg}^{-1}$ dry matter) of ingredients of experimental diets

\begin{tabular}{|c|c|c|c|c|c|}
\hline \multirow[b]{2}{*}{ Item } & \multirow[b]{2}{*}{ Sugar Cane } & \multicolumn{2}{|c|}{ Ingredient } & \multirow[b]{2}{*}{$\begin{array}{c}\text { Mineral } \\
\text { Salt }\end{array}$} & \multirow[b]{2}{*}{$\begin{array}{l}\text { Dicalcium } \\
\text { Phosphate }\end{array}$} \\
\hline & & Corn Silage & $\begin{array}{l}\text { Soybean } \\
\text { meal }\end{array}$ & & \\
\hline Dry matter & 291.0 & 299.4 & 880.0 & 997.0 & 961.8 \\
\hline Crude protein ${ }^{1}$ & 27.4 & 63.1 & 500.0 & - & - \\
\hline $\mathrm{NDF}$ & 567.5 & 532.0 & 142.0 & - & - \\
\hline $\mathrm{ADF}$ & 362.2 & 325.9 & 94.0 & - & - \\
\hline NFC & 374.1 & 345.6 & 281.0 & - & - \\
\hline Total minerals, & 22.8 & 37.6 & 61.0 & $1,000.0$ & $1,000.0$ \\
\hline Calcium & 1.4 & 1.4 & 3.0 & 115.6 & 204.5 \\
\hline Phosphorus & 0.6 & 2.0 & 7.2 & 94.9 & 163.8 \\
\hline Magnesium & 0.6 & 1.5 & 3.1 & 17.8 & - \\
\hline Potassium & 9.0 & 14.3 & 25.3 & 4.4 & - \\
\hline Sulfur & 0.5 & 1.3 & 5.0 & 37.7 & - \\
\hline Sodium & 0.1 & 0.1 & 2.2 & 131.7 & - \\
\hline Zinc, $\mathrm{mg} \mathrm{kg}^{-1}$ & 6 & 20 & 55 & 4,327 & - \\
\hline Cobre, $\mathrm{mg} \mathrm{kg}^{-1}$ & 3 & 6 & 19 & 1,937 & - \\
\hline Manganese, $\mathrm{mg} \mathrm{kg}^{-1}$ & 60 & 67 & 40 & 2,521 & - \\
\hline Iron, $\mathrm{mg} \mathrm{kg}^{-1}$ & 293 & 795 & 33 & 6,259 & - \\
\hline
\end{tabular}

${ }^{1}$ Crude protein or protein equivalent ( $\mathrm{g} \mathrm{x}$ x 6.25).

Average weight gain, average dry matter and crude protein intake from sugar cane, corn silage and mineral salt and their relation with weight gain are shown in Table 3. There was a significant $(\mathrm{P}<0.05)$ effect of treatments on the calf weight gain. Supplementation with minerals, which are deficient in sugar cane in relation to calf requirements, mixed with forage (MA) instead of being offered ad libitum in trough $(\mathrm{MT})$ resulted in greater ADG $(0.258 \mathrm{x}$ $0.188 \mathrm{~kg} / \mathrm{calf}$ ). Calves eating minerals under forced conditions had greater ADG, which could be explained by the fact that the amount and frequency was variable when eaten ad libitum and was not related to their requirements (McDowell, 1996). The efficacy of supplementation employing forced intake when calves are fed concentrates is based on the fact that the palatability of the concentrate overcomes the different acceptance levels and highly individual variations in mineral mixture intake by ruminants when offered ad libitum (Coppock et al., 1972).

These findings can be extrapolated to forages in which higher palatability prevails over mineral mixtures. Sugar cane and corn silage fit well among these forages. The addition of ten grams of a mixture of nine parts of urea to one of ammonium sulfate per $\mathrm{kg}$ of fresh chopped sugar cane in feeding of ruminants was recommended by Alvarez and Preston (1976) and widely reported by Moreira (1983) and Torres and Rodrigues (2007) in Brazil. The purpose of this concentrate was to add a source of ammonia and sulfur for the synthesis of amino acids by the ruminal microorganisms. However, there is evidence that other macro and microminerals are needed by ruminal microorganisms in ruminal fermentation. Mixing all of the minerals with sugar cane makes them available for rumen fermentation with each mouthful the calf swallows. This does not happen when the calf licks it in the trough obtaining varied amounts with different frequency.

The greater average weight gain of calves that received the minerals along with the urea and ammonium sulfate (MA) may have been the result of better efficiency in the utilization of the nutrients because no effect on dry matter intake was observed $(3.29 \times 3.30 \mathrm{~kg})$. This greater efficiency was reflected by the lower amount of sugar cane ingested per $\mathrm{kg}$ of weight gain (16.80 $x$ 12.13). The weight gain observed in this experiment is in agreement with Preston and 
Leng (1978) and Boin and Tedeshi (1993) who reported that when sugar cane was supplemented with urea and minerals only, the nutrients supplied were only adequate for maintenance and low weight gains. The data in this experiment indicate that adding minerals to the urea and ammonium sulfate and mixing them with chopped fresh sugar cane resulted in a significant increase in weight gain without additional cost and then a more efficient way of supplying the minerals to calves. Substitution of part of the urea nitrogen in the concentrate containing urea, ammonium sulfate and minerals (MA) with the protein equivalent in the soybean meal (SU) resulted in significant $(\mathrm{P}<0.05)$ increase in ADG $(0.538 \times 0.258)$. This was partly due to the $31.30 \%$ increase in sugar cane dry matter intake $\left(3.13 \times 4.11 \mathrm{~kg} \mathrm{~d}^{-1}\right)$ by calves. The amount of sugar cane dry matter intake per unit of weight gain indicated higher efficiency of nutrient utilization by calves when soybean meal partially replaced urea as a source of nitrogen (7.64 $\mathrm{x} 12.13$ ) in the diet. The intake of feed with low nitrogen content is limited due to the reduction of ruminal fermentation.

Table 3. Average daily gain, sugar cane, corn silage, total dry matter, crude protein and mineral intakes by calves fed sugar cane different concentrates added to sugar cane and corn silage as the only forage

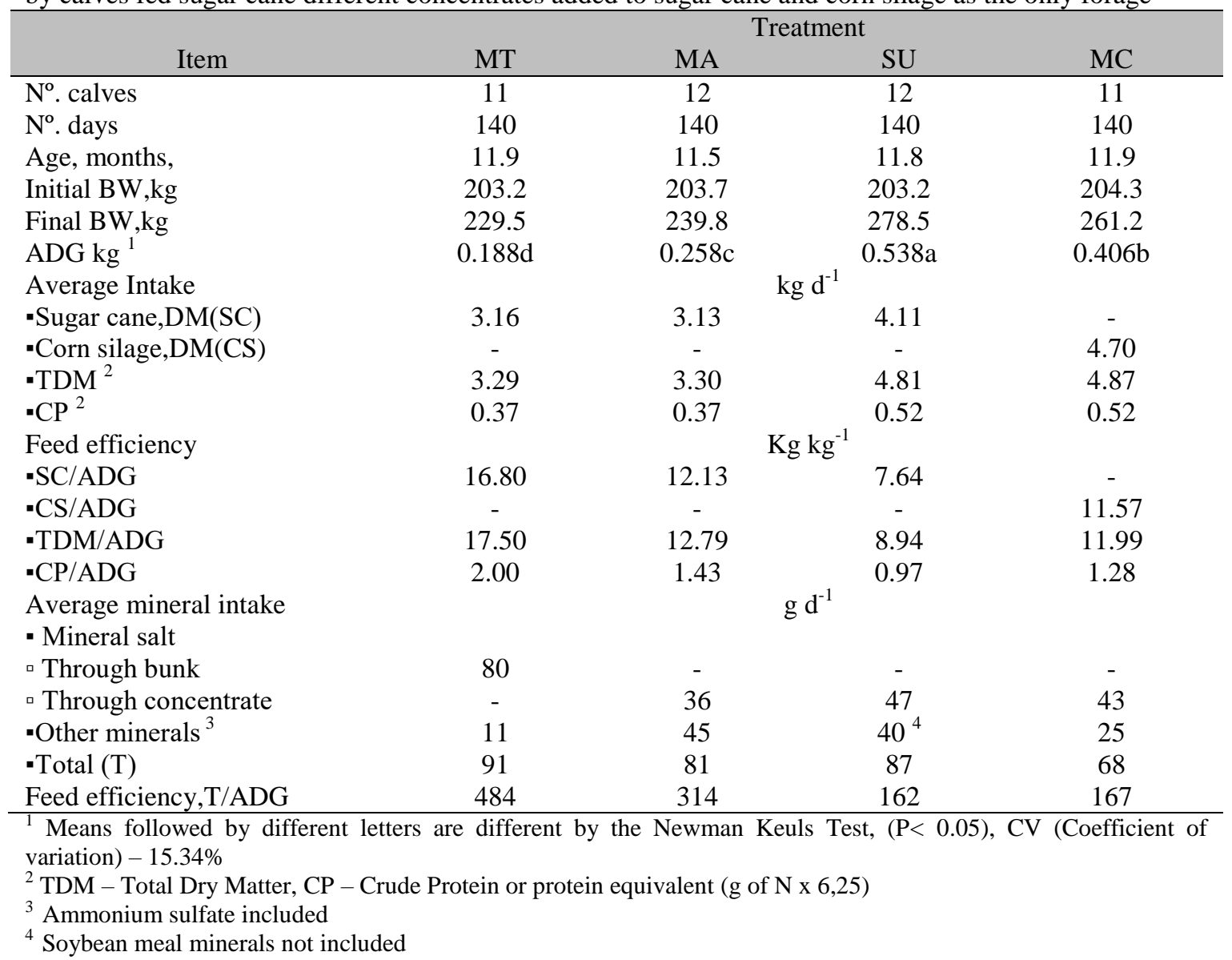

However in the treatments in which the nitrogen levels were corrected, the sugar cane intake remained low. This is in agreement with Ferrero et al. (1977) that noticed no effect in dry matter intake and only a small increase in digestibility when the nitrogen content of sugar cane was corrected with urea. The accumulation of non- digestible fiber in the rumen limits the voluntary intake (Orskov and Hovell, 1978). In the fiber digestion process the bacteria that act on cellulose require a minimum level of nitrogen that can be supplied by sources of non-protein nitrogen. However, these bacteria also require branched volatile fatty acids that can originate 
from aminoacids of rumen degraded protein (Bryant, 1973). Even a small increase in sugar cane fiber digestibility in the presence of branched chain volatile fatty acids would not be enough to explain the increase in intake due to the substitution of urea with soybean meal in the SU treatment, because the sugar cane fiber digestibility is very low (Costa et al., 2005).

An increase in microbial growth has been reported when peptides and some amino acids replace urea or ammonia as the only nitrogen source in the diet (Russel and Sniffen, 1984; Griswold et al., 1996). Preston (1982) reported that the most important factor in sugar cane utilization is the non-degraded protein in the rumen and its availability in the duodenum. He reported that the effect of this protein, besides supplying amino acids for the synthesis of milk and body tissue is to promote increased intake and rumen function. The addition of $1.2 \mathrm{~kg}$ of rice bran in a diet based on sugar cane increased the weight gain of steers from $150 \mathrm{~g}$ to $900 \mathrm{~g}$ per day (Preston et al., 1976). They reported that, besides the protein in the rice bran, great weight gain was also due to other nutrients, such as lipids and starch, in rice bran. In the soybean meal treatment (SU), 24 to $31 \%$ of the protein supplied by soybean meal in the rumen was in the non-degraded form (Nutrient..., 2001). In this experiment, using $27 \%$ as the average content of ruminal undegraded protein in the soybean meal, it was calculated that 78 gram would be available daily for absorption in the small intestine. However, besides the undegraded protein in the rumen, another component of the diet that may have contributed to the best calf performance was the degradable protein of the soybean meal in the rumen that according to the calculation above was around $210 \mathrm{~g}$.

Amino acids and peptides from protein degradation are utilized by the bacteria that ferment nonstructural carbohydrates (Russel et al., 1992) as well as being sources of branched chain volatile fatty acids utilized by the bacteria that ferment the cellulose (Bryant, 1973). According to Lima et al. (2002) in the previous decades the concept of ruminal resistance to degradation of some nutrients in feed, with the purpose of greater availability of them in the small intestine is important, however, if the level of protected nutrients in the rumen is too high the amount of non protected nutrients could compromise the ruminal microorganisms growth by reducing their population, rate of ruminal fermentation, the digestion of fiber and non-fiber fraction, and also, the animal performance. The concept of protected nutrients is important for the best utilization of feed by ruminants but it is necessary that the amounts and balance of other nutrients are adequate so they will be available for the highest efficiency of fermentation by the microorganisms in the rumen. It was reported by Thomsen (1985) that proteins of high degradability such as casein or those contained in soybean meal or long peptides, either doubled the digestibility of starch or increased the digestibility of cellulose when compared with the digestibility of these two nutrients supplemented with urea or aminoacids. Balancing of sugar cane with a source of non-protein nitrogen supplies ammonia for the bacteria that utilize available fiber carbohydrate for fermentation. However, these carbohydrates in sugar cane have low digestibility (Valdez and Leng, 1976) and their contribution to energy is not as important as that of non-fiber carbohydrates, which is mainly sucrose.

Non-fiber carbohydrates are an important part of the dry matter of sugar cane which is fermented by bacteria that mainly utilize peptides and amino-acids as a source of nitrogen (Russel et al., 1992). Calves fed the concentrate from soybean meal had the best performance, mainly due to the high efficiency of utilization of non fiber carbohydrate of the sugar cane in the rumen. Supplementation with the concentrate containing soybean meal as source of peptides and aminoacids resulted in greater ruminal fermentation due to an adequate balance of nutrients that probably met the requirements of the microorganisms in diet with sugar cane and urea which is rich in non fiber carbohydrates. Higher fermentation rates result in higher turnover rates in response to supplementation from degradable protein sources in the rumen (Hunter and Siebert, 1987). In this experiment, the relationship between the dry matter intake of sugar cane and weight gain indicated greater efficiency of the diet that contained soybean meal replacing urea $(7.64 \times 12.13)$ on a nitrogen equivalent basis.

The daily weight gain of calves fed corn silage with urea, ammonium sulfate and minerals (MC) was significantly $(\mathrm{P}<0.05)$ greater than those fed 
sugar cane with urea, ammonium sulfate and minerals $\left(0.406 \times 0.258 \mathrm{~kg} \mathrm{~d}^{-1}\right)$. This increase in weight gain can be attributed to a larger intake of corn silage in relation to sugar cane $(4.71 \mathrm{x}$ $\left.3.13 \mathrm{~kg} \mathrm{~d}^{-1}\right)$. The sugar cane and corn silage showed similar NDF contents of 567.5 and $532.0 \mathrm{~g} \mathrm{~kg}^{-1}$, respectively. However, one of the main causes of dry matter intake limitation is the accumulation of indigestible NDF in the rumen (Orskov and Hovell, 1978).

The cell wall digestibility of sugar cane intake is lower than that of corn silage (Mendonça et al., 2004), so a larger dry matter intake from corn silage is needed to provide the same amount of indigestible fiber residue in the rumen as a lower intake from sugar cane in a 24 hour period. Mendonça et al. (2004) reported a significant difference in the daily dry matter intake of complete diets with sugar cane and corn silage, 14.4 and $17.8 \mathrm{~kg}$ per lactating cow, respectively. After calculating the daily amount of indigestible NDF consumed, they found similar values for both experimental diets. In the present experiment, there was enough non-protein nitrogen in the concentrate with urea, ammonium sulfate and minerals for fermentation of corn silage fiber and sugar cane fiber. The non-fiber carbohydrate contents of sugar cane and corn silage ( 345.6 and $374.1 \mathrm{~g} \mathrm{~kg}^{-1}$ ), respectively, were similar but differed in composition; sugar cane was mainly sucrose and corn silage was mainly starch. The bacteria that ferment non-fiber carbohydrates require the availability of protein supplement that supply peptides and aminoacids for higher efficiency (Russel et al., 1992).

In the present experiment, concentrates for both sugar cane and corn silage had urea and ammonium sulfate as the only nitrogen source. However the crude protein content of the corn silage was greater than that of the sugar cane and could explain the better utilization of its nonfiber carbohydrate content. The relationship between dry matter intake and weight gain indicated that efficiency of utilization of nutrients from corn silage and sugar cane were not very different, being 11.99 and 12.79, respectively. The larger weight gains of the calves fed corn silage were probably due to better cell wall digestibility, better utilization of non fiber carbohydrates and a higher turnover rate, resulting in a greater dry matter intake. In Table 4 the nutrient intake and their relationship to ADG are shown.

Table 4. Average daily intake of crude protein, non-fiber carbohydrate, neutral detergent fiber, acid detergent fiber and their relationship to the average daily gain of calves

\begin{tabular}{|c|c|c|c|c|}
\hline \multirow[b]{2}{*}{ Item } & \multicolumn{4}{|c|}{ Treatment } \\
\hline & MT & MA & SU & $\mathrm{MC}$ \\
\hline $\mathrm{ADG}, \mathrm{kg}$ & 0.188 & 0.258 & 0.538 & 0.406 \\
\hline Average intake & \multicolumn{4}{|c|}{$\mathrm{kg} \mathrm{d}^{-1}$} \\
\hline$\cdot \mathrm{CP}^{1}$ & 0.37 & 0.37 & 0.52 & 0.52 \\
\hline -NFC & 1.19 & 1.19 & 1.75 & 1.66 \\
\hline -NDF & 1.79 & 1.76 & 2.38 & 2.48 \\
\hline -ADF & 1.13 & 1.11 & 1.52 & 1.52 \\
\hline Rate, Intake/ADG & \multicolumn{4}{|c|}{$\mathrm{kg} \mathrm{kg}^{-1}$} \\
\hline$\cdot \mathrm{CP} / \mathrm{ADG}$ & 2.00 & 1.43 & 0.97 & 1.28 \\
\hline -NFC/ADG & 6.32 & 4.61 & 3.25 & 4.09 \\
\hline -NDF/ADG & 9.52 & 6.82 & 4.42 & 6.11 \\
\hline -ADF/ADG & 6.01 & 4.30 & 2.82 & 3.74 \\
\hline
\end{tabular}

${ }^{1}$ Crude protein or Protein equivalent (g N x 6.25)

The CP, NFC, NDF and ADF intakes were associated with dry matter intake. The rates between intake of CP and NFC to ADG indicated higher efficiency of utilization of these nutrients in weight gain, in the SU treatment. The NDF intakes as $\mathrm{g}$ per $\mathrm{kg}$ of live weight were 8.3, 7.9,
9.9 and 10.6 for the sugar cane forage based treatments with urea as the nitrogen source (MT and MA), for urea and soybean meal (SU) and for the corn silage treatment with urea and minerals (MC), respectively. Mendonça et al. (2004) reported contents of 474 and $310 \mathrm{~g}$ of 
digestible FDN kg-1 dry matter in corn silage and sugar cane, respectively, in complete diets for lactating cows. They reported that the average dry matter intakes of the corn silage and sugar cane diet were 17.8 and $14.7 \mathrm{~kg}$, respectively. In the present experiment, applying the rates of NDF indigestibility for sugar cane and corn silage found by Mendonça et al. (2004), the calculated indigestible NDF intakes in the MA and $\mathrm{MC}$ treatments were 5.40 and $5.60 \mathrm{~g} \mathrm{~kg}^{-1}$ of live weight, respectively, similar for both forages. Thus when corn silage and sugar cane were supplemented with urea and minerals the forage intake varied mainly due to differences in their fiber digestibility and different turnover rates.

\section{CONCLUSIONS}

Crossbred calves ( $3 / 4$ Zebu $x$ Holstein) that received mineral salt supplementation mixed with sugar cane nitromineral concentrate showed greater weight gain and feed efficiency than those supplemented ad libitum in the trough. Substitution of part of the urea nitrogen in the sugar cane nitromineral concentrate with an equivalent amount of nitrogen from soybean meal resulted in greater weight gain, sugar cane intake and feed efficiency, indicating that the presence of true protein increased the efficiency of sucrose utilization of sugar cane. The calves fed corn silage mixed with a nitromineral concentrate had greater weight gain than those fed sugar cane mixed with the nitromineral sugar cane concentrate. The recommendation for feeding urea and ammonium sulfate mixed with sugar cane is widely used in Brazil. Feeding minerals, along with urea and ammonium sulfate, and replacing part of the urea with soybean meal and mixing these with sugar cane resulted in better performance.

\section{AKNOWLEDGENT}

The authors want to thank for the financial support provided by the Fundação de Amparo a Pesquisa do Estado de Minas Gerais FAPEMIG (PPM 00558-16), FINEP and MCTI (Project 1334/13), to INCT-Ciencia Animal and to the valuable support of Marilyn Noller for the English review.

\section{REFERENCES}

ALLEN, S.A.; MILLER, E.R. Determination of nitrogen requirement for microbial growth from the effect of urea supplementation of a low $\mathrm{N}$ diet on abomasal $\mathrm{N}$ flow and $\mathrm{N}$ recycling in wethers and lambs. Br. J. Nutr., v.36, p.353-368, 1977.

ALVAREZ, F.J.; PRESTON, T.R. Studies on urea utilization in sugar cane diets: effect of level. Trop. Anim. Prod., v.1, p.194-201, 1976.

BOIN, C.; TEDESHI, L.O. Cana-de-açúcar na alimentação de gado de corte. In: Simpósio sobre nutrição de bovinos, 5., 1993, Piracicaba. Anais... Piracicaba: FEALQ, 1993. p.107-126.

BRYANT, M.P. Nutritional requirement of the predominant rumen cellulolytic bacteria. Fed. Proc., v.32, p.1809, 1973.

COPPOCK, C.E.; EVERETT, R.W.; MERRIL, W.G. Effect of ration on free choice consumption of calcium-phosphorus supplements by dairy cattle. J. Dairy Sci., v.55, p.245-256, 1972.

COSTA, M.G.; CAMPOS, J.M.S.D.; VALADARES FILHO, S.C. et al. Desempenho produtivo de vaca leiteiras alimentadas com diferentes proporções de cana-de-açúcar e concentrado ou silagem de milho na dieta. Rev. Bras. Zootec., v.34, Suppl., p.2437-2445, 2005.

FERRERO, H.M.; PRESTON, T.R.; SUTHERLAND, T.M. Investigation on sugar cane based diets. Trop. Anim. Prod., v.2, p.5661, 1977.

GOERING, H.K., VAN SOEST, P.J. Forage fiber analysis (apparatus, reagents, procedures and some applications). Agric Handbook, n. 379, Agric. Res. Serv., US Dept. Agric., Washington. DC, 1970.

GRISWOLD, K.E.; HOOVER, W.V.; MILLER, T.K.; THAYNE, W.V. Effect of form of nitrogen on growth of ruminal microbes in continuous culture. J. Anim. Sci., v.74, p.483-491, 1996.

HUNTER, R.A.; SIEBERT, B.D. The effect of supplements of rumen-degradable protein and formaldehyde-treated casein on the intake of the low-nitrogen roughages by Bos Taurus and Bos indicus steers at different stages of maturity. Aust. J. Agric. Res., v.38, p.219-218, 1987. 
LIMA, L.G.; NUSSIO, L.G.; GONÇALVES, J.R.S. et al 2002. Fontes de amido e proteína para vacas leiteiras em dietas a base de capim elefante. Sci. Agríc., v.59, p.19-27, 2002.

MAGALHÃES, A.I.R.; CAMPOS, J.M.S.; VALADARES FILHO, S.C. et al. Cana-deaçúcar em substituição à silagem de milho em dietas para vacas em lactação: desempenho e viabilidade econômica. Rev. Bras. Zootec., v.33, p.1292-1302, 2004.

MCDOWELL, L.R. Free choice mineral supplementation for grazing ruminants. Arch. Lat. Prod. Anim., v.1, p.1-8, 1993.

MCDOWELL, L.R. Feeding minerals to cattle on pasture. Anim. Feed Sci. Technol., v.60, p.247-271, 1996.

MENDONÇA, S.S.; CAMPOS, J.M.S.; VALADARES FILHO, S.C. et al. Consumo, digestibilidade aparente, produção e composição do leite e variáveis ruminais em vacas leiteiras alimentadas com dietas à base de cana-de-açúcar. Rev. Bras. Zootec., v.33, p.481-492. 2004.

MOREIRA, H.A. Cana-de-açúcar na alimentação de bovinos. Inf. Agropecu., v.9, p.14-16, 1983.

NUTRIENT requirements of dairy cattle. 7.ed., rev. Washington: National Academy of Science, 2001. 381p.

OFFICIAL methods.16.ed. Virginia: AOAC International, 1995.1094p.

OLIVEIRA, M.D.S.; CASA GRANDE, A.A.; OLIVEIRA, E.F.S. Efeito da digestibilidade in vitro de variedades de cana-de-açucar sobre seu valor como alimento para bovinos. ARS Veterinaria, v.17, p.238-243,2001.

ORSKOV, E.R.; HOVELL, F.D.B. Rumen digestion of hay (measured with dacron bags) by cattle given sugar cane or pangola hay. Trop. Anim. Prod., v.2, p.125, 1978.

PRESTON, T.R. Nutritional limitations associated with the feeding of tropical forages. $J$. Anim. Sci., v.54, p.877-884, 1982.
PRESTON, T.R.; CARCANO, C.; ALVAREZ, F.J.; GUTIERREZ, D.G. Rice polishings as a supplement in a sugar cane diet: effect of level of rice polishings and of processing the sugar cane by deriding or chopping. Trop. Anim. Prod., v.1, p.150-161, 1976.PRESTON, T.R.; LENG, R.A. Sugar cane as cattle feed. Part 1: nutritional constraints and perspectives. Worl. Anim. Rev., v.27, p.7-12, 1978.

RUSSEL, J.B.; O`CONNOR, J.D.; FOX, D.J. et al. Net carbohydrate and protein system for evaluating cattle diets: I. Ruminal fermentation. J. Anim. Sci., v.70, p.3551-3561, 1992.

RUSSEL, J.B.; SNIFFEN, C.J. Effect of carbon4 and carbon-5 volatile fatty acids on growth of mixed rumen bacteria in vitro. J. Dairy Sci., v.67, p.987-994, 1984.

THOMSEN, K.V. The specific nitrogen requirements of rúmen microorganisms. Acta Agric. Scand., v.25, Suppl., p.125, 1985.

TORRES, R.A.; RODRIGUES, C.A.F. Cana de açúcar + uréia: uma excelente alternativa para suplementar os bovinos no período seco do ano. In: Tecnologias para o Desenvolvimento da Pecuária de Leite Familiar no Norte de Minas e Vale do Jequitinhonha. 2007, Embrapa Gado de Leite, Juiz de Fora, MG, Brasil, 2007. p.129-140.

VALADARES FILHO, S.C.; MAGALHÃES, K. A.; ROCHA JUNIOR, V.R.; et al. Tabelas Brasileiras de Composição de Alimentos para Bovinos. $2^{\text {a }}$ Ed. Viçosa: Universidade Federal de Viçosa, MG, Brasil. 2006. 329p.

VALDEZ, R.E.; LENG, R.A. In vivo digestion of fibre in sugar cane. Trop. Anim. Prod., v.1, p.50, 1976.

VAN SOEST, P.J.; ROBERTSON, J.B.; LEWIS, B.A. Methods for dietary fiber, neutral detergent fiber and non starch polysaccharides in relation to animal nutrition. J. Dairy Sci., v.74, p.35833597, 1991. 